\title{
Peritumoral brain edema in intracranial meningiomas
}

\author{
Nelson de Azambuja Pereira-Filho', Fabiano Pasqualotto Soares², \\ Ivan de Mello Chemale ${ }^{3}$, Ligia Maria Barbosa Coutinho ${ }^{4}$
}

\begin{abstract}
Occurrence of peritumoral brain edema (PBE) in meningiomas has been associated with several factors in recent years, although its pathophysiological mechanism has not yet been fully elucidated. The aim of this study was to analyze the correlation between the presence / degree of PBE and factors such as gender, age, size and histological subtype of tumor. We analyzed the MRI images of 74 patients operated on Hospital Beneficência Portuguesa de Porto Alegre for the presence / degree of PBE and data was statistically correlated with the parameters of the patient. PBE was present in $70.1 \%$ of patients. Tumors with higher volume had more PBE. Tumors of the olfactory groove showed more PBE than sphenoid wing and parassagittal tumors. Transitional subtype showed more PBE than fibroblastic and meningothelial subtypes.
\end{abstract}

Key words: brain edema, meningioma, peritumoral brain edema.

\section{Edema peritumoral em meningiomas intracranianos}

\section{RESUMO}

A presença de edema cerebral peritumoral (ECP) em meningiomas tem sido associada a diversos fatores nos últimos anos, embora o seu mecanismo fisiopatológico ainda não tenha sido inteiramente elucidado. O objetivo desse estudo foi analisar a correlação entre a presença/grau de ECP e fatores como sexo, idade, volume e subtipo histológico do tumor. Foram analisadas imagens de RM de 74 pacientes operados no Hospital Beneficência Portuguesa de Porto Alegre quanto à presença/grau de ECP e os dados correlacionados estatisticamente com os parâmetros do paciente. ECP estava presente em 70,1\% dos pacientes. Tumores com maior volume apresentaram mais ECP. Tumores da goteira olfatória apresentaram mais ECP que os da asa do esfenóide e que os parassagitais. Meningiomas transicionais apresentaram mais ECP que os fibroblásticos e que os meningoteliais. Palavras-chave: edema encefálico, meningioma, edema cerebral peritumoral.

Formerly used by Harvey Cushing in the beginning of the last century ${ }^{1}$, the word meningioma applies to tumors originated from the meningothelial cells from arachnoid ${ }^{2}$. These tumors account for approximately $15 \%$ of intracranial tumors and occur mainly between fourth and sixth decades of life, affecting predomi- nantly women ${ }^{3}$. They are slow-growing tumors and usually have benign behavior, reasons for which they are frequently diagnosed late ${ }^{3}$. The presence of peritumoral brain edema (PBE) in meningiomas is well-known for a long time and has been the subject of several studies concerning its physiopathogeny. PBE can lead to tech-

\section{Correspondence}

Fabiano Pasqualotto Soares Serviço de Neurologia e Neurocirurgia Dr. Mário Coutinho Av. Independência 270 90035-070 Porto Alegre RS- Brasil E-mail: fabianoslasher@gmail.com

Received 13 August 2009

Received in final form 1 September 2009

Accepted 9 September 2009
Hospital Beneficência Portuguesa de Porto Alegre, Porto Alegre RS, Brazil: 'Neurosurgeon of Serviço de Neurologia e Neurocirurgia Dr. Mario Ferreira Coutinho, Hospital Beneficência Portuguesa de Porto Alegre, Master's program graduate of Universidade Federal de Ciências da Saúde de Porto Alegre; ${ }^{2}$ Resident of Serviço de Neurologia e Neurocirurgia Dr. Mario Ferreira Coutinho, Hospital Beneficência Portuguesa de Porto Alegre; ${ }^{3}$ Associate Professor of Neurosurgery at the Universidade Federal de Ciências da Saúde de Porto Alegre, Head of the Serviço de Neurologia e Neurocirurgia Dr. Mario Ferreira Coutinho, Hospital Beneficência Portuguesa de Porto Alegre; ${ }^{4}$ Professor Emeritus of Universidade Federal de Ciências da Saúde de Porto Alegre, Professor of the Post-Graduation in Pathology, Universidade Federal de Ciências da Saúde de Porto Alegre. 
nical difficulties in surgical treatment, such as operatory field limitation, when PBE is extensive $e^{4,5}$.

There are no definite causes yet for the PBE occurrence ${ }^{6}$. Nevertheless, some factors have been associated with their presence, such as the location of the tumor ${ }^{7}$, its size ${ }^{7}$ age $^{8}$ and sex of the patient ${ }^{9}$.

In this study, we analyzed retrospectively radiographic images of 74 patients undergoing meningioma surgery at Hospital Beneficência Portuguesa de Porto Alegre. We examined the existence of correlation between parameters such as age, sex and location of the tumor and the presence/degree of $\mathrm{PBE}$.

\section{METHOD}

We randomly selected 74 patients which underwent meningioma surgery in the Department of Neurosurgery at the Hospital Beneficência Portuguesa de Porto Alegre between 2004 and 2008. The parameters analyzed were patient's age at the time of MRI workup, sex, size, location of tumor, histological subtype and presence/degree of PBE.

The parameters related to the morphological characteristics of the tumors were analyzed using the images obtained from magnetic resonance imaging. To estimate the volume of tumor we used the ellipsoid formula $V=4 / 3 . \pi . a b c$, in which a, b and c are, respectively, the axial, coronal and sagital largest diameters. The presence of edema was investigated using the FLAIR sequence or, when not available, the T2 sequence. Edema, if present, was classified subjectively as bigger than the tumor (Fig 1), similar to the tumor or smaller than the tumor (Fig 2).

Statistical analysis of data was performed using the tools of data analysis software of Microsoft Excel 2007. We considered significant a $\mathrm{p}<0.05$.

\section{RESULTS}

From the selected patients, 45 were female and 29 male. Age ranged between 20 and 84 years (mean: 56.9, standard deviation: 12.45$)$. The average tumor volume was $129.8 \mathrm{~cm}^{3}$ (median $60.1 \mathrm{~cm}^{3}$ ), ranging from 8.5 to 916.8 $\mathrm{cm}^{3}$. Peritumoral edema was present in 52 patients (70\%). When present, it was was smaller than the tumor in 33 cases, similar to the tumor in 7 cases and bigger than the tumor in 12 cases. The most frequent sites was sphenoid wing (17.5\%), parassagittal (14.8\%), frontal convexity $(13.5 \%)$ and olfactory groove (13.5\%). The most frequent histological subtypes were transitional (37.0\%), meningothelial (27.7\%) and fibroblastic (11.1\%).

The presence and degree of edema does not significantly correlated with the sex of the patient. The mean age of the patients did not differ significantly between patients with tumors with and without PBE ( $\mathrm{p}=0.32$, $\mathrm{t}$ test). Concerning volume, tumors were categorized into larger or smaller than the median volume. There was no statistically significant difference between these two groups regarding the presence and degree of PBE (chi-square test). The average volume of tumors with PBE $\left(205.0 \mathrm{~cm}^{3}\right) \mathrm{com}$ pared to the average volume of tumors without PBE (79.4 $\left.\mathrm{cm}^{3}\right)$ was significantly higher $(\mathrm{p}=0.015$, $\mathrm{t}$ test). Comparing the presence and degree of PBE versus more frequent location with the chi-square test, no statistically significant correlation was obtained. There was found, however, that the presence of PBE in tumors located in the olfactory groove is significantly higher than in tumors of the sphenoid wing ( $\mathrm{p}=0.013$, $\mathrm{t}$ test) and in parassagittal tumors $(\mathrm{p}=0.017)$, but has no significant difference between frontal tumors $(p=0.16)$. There was no significant difference in the individual comparison between the other locations. There was no statistically significant difference between the subtype of tumor and the degree of edema. The presence of edema, however, was significantly higher in the transitional subtype than in fibroblastic $(\mathrm{p}=0.001)$ and meningothelial subtypes ( $\mathrm{p}=0.018$ ). There was no significant difference between the fibroblastic and meningothelial subtypes ( $\mathrm{p}=0.14$ ) (Fig 3 ).
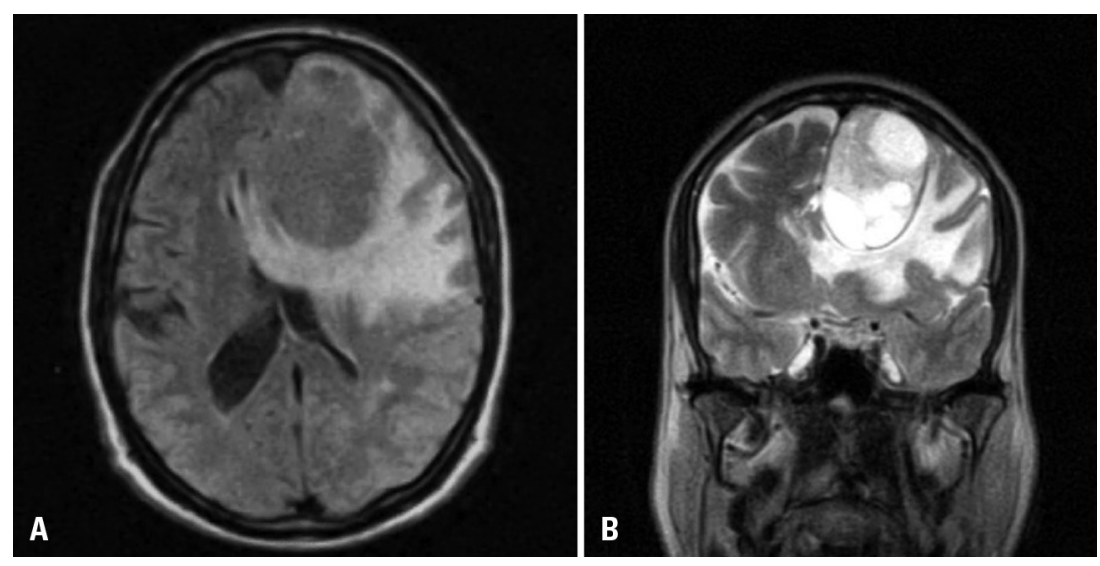

Fig 1. MRI images showing a parassagittal meningioma with PBE classified as bigger than the tumor. Axial FLAIR image $[A]$ and coronal T2 image [B].

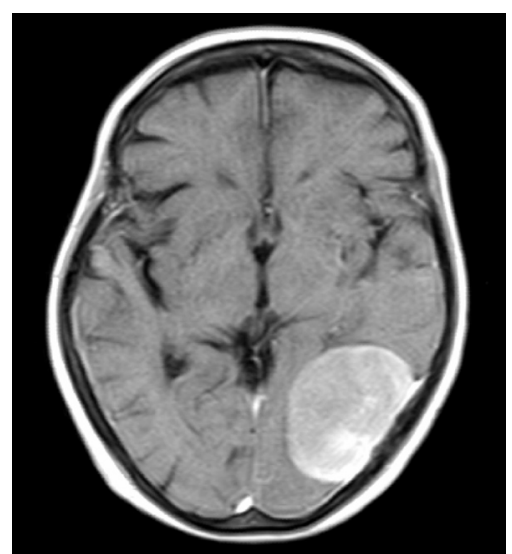

Fig 2. T1 image showing a parieto-ocipital convexity meningioma without edema. 
A
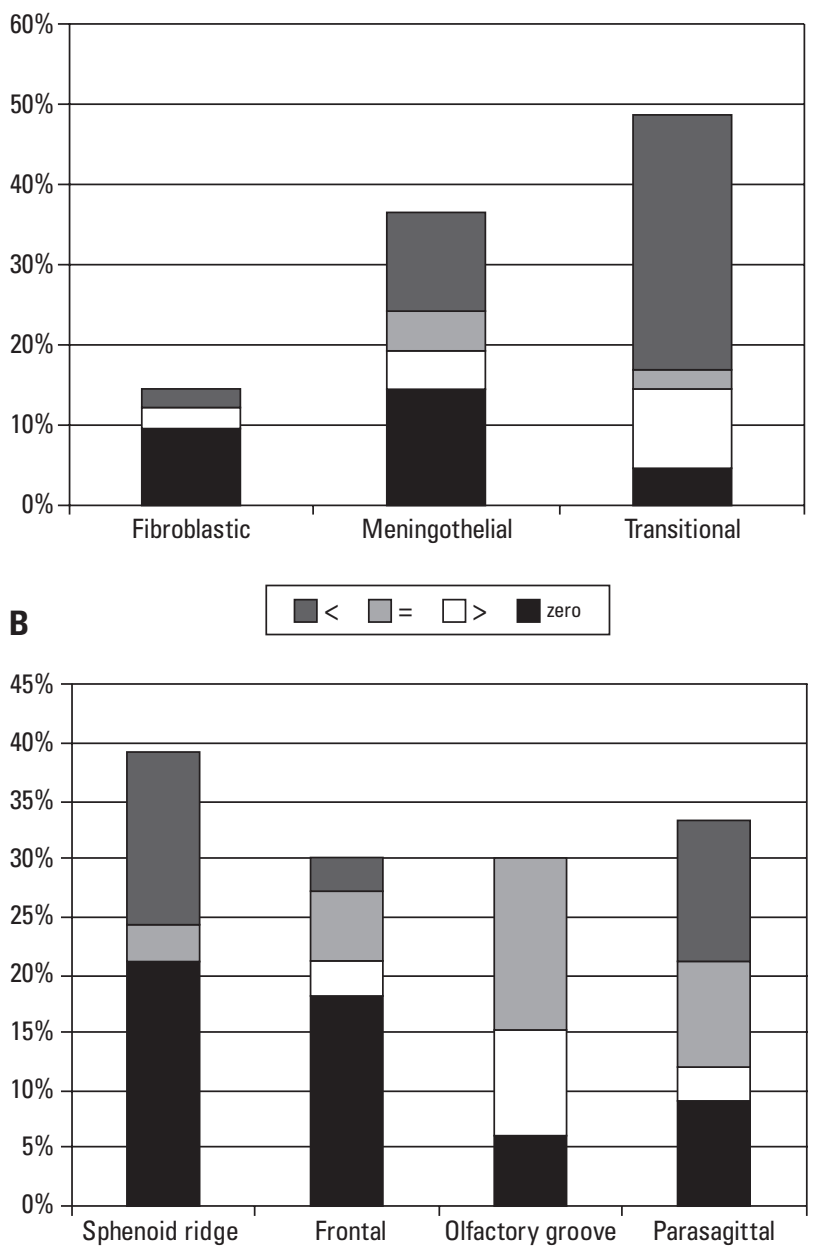

$\square<\square=\square>\square$ zero

Fig 3. Occurrence and grade of PBE in relation to the more prevalent histological subtypes [A] and locations $[B]$.

\section{DISCUSSION}

The presence of PBE in meningiomas is a constant in medical literature ${ }^{9-12}$. In this series, PBE was found in $70.2 \%$ of patients, data that agrees with results of previous studies, which show great variation in the prevalence of PBE. Souto et al suggest that PBE variation between the series is probably due to the difference in criteria used to consider significant the presence of $\mathrm{PBE}^{7}$.

$\mathrm{PBE}$ is a factor associated with increased perioperative morbidity, because it can create technical difficulties in addressing the tumor (by limiting the surgical field) ${ }^{4,5}$, cause / exacerbate neurological deficits ${ }^{4,5}$, in addition to being associated with increased length of hospital stay and increased risk of hematoma and intracranial hypertension in the postoperative period ${ }^{5}$.

We found no significant correlation between the presence / degree of PBE and the age and sex of patients. This finding is consistent with most available data in the medical literature ${ }^{6}$, although Lee and collaborators ${ }^{9}$ have found higher incidence of PBE in males than in females and age between 61 and 70 years was correlated with a higher degree of PBE in a study performed by Gurkanlar and collaborators ${ }^{8}$.

Our study showed that tumors with PBE have bigger volumes than tumors without PBE. This finding is supported by the literature $e^{6,7,9,11}$, although some studies have not found a significant correlation between tumor volume and $\mathrm{PBE}^{8,12}$. Studies show that some patients with meningiomas have a decreased peritumoral blood flow and conclude that the edema may have an ischemic component, because of compression of adjacent brain tissue caused by the tumor ${ }^{10}$, in addition to vasogenic edema commonly described. The vasogenic edema is related to increased vascular permeability caused by substances produced by the tumor. Studies have shown correlation between PBE and the expression of certain molecules such as VEGF (vascular endothelial growth factor) and MMF-9 (matrix metalloproteinase-9) ${ }^{12}$.

Although significant part of previous studies did not observe correlation between tumor site and the presence of $\mathrm{PBE}^{8,9,11}$, some studies have suggested the sphenoid wing as the location most associated with $\mathrm{PBE}^{7}$. Results obtained in our study disagree with these data, however. Tumors located in the olfactory groove showed more PBE than tumors of the sphenoid wing and parassagittal. The olfactory groove is a location that, due to their anatomical characteristics, allows a tumor located there to have a substantial growth before causing symptoms. Thus, with the late clinical presentation of the tumor, there would be more time for the establishment of the PBE prior to its detection.

Meningiomas of the transitional subtype had significantly more PBE than the meningothelial and fibroblastic subtypes. This data contrasts partially with the literature because, although there are studies showing increased presence of PBE in more aggressive subtypes (atypical, malignant) compared to other subtypes ${ }^{9}$, most studies found no significant correlation between histological subtype and $\mathrm{PBE}^{7,8,11}$.

PBE was found in $70.1 \%$ of cases. Gender and age are not correlated with the presence and degree of PBE. Tumors with PBE was bigger when compared to those without PBE. Tumors located in the olfactory groove showed more PBE compared to tumors of sphenoid wing and parassagittals. Meningiomas of the transitional subtype had more PBE than fibroblastic and meningothelial subtypes.

Despite the data in the literature to date, together with the results of this study, further studies are still needed to the complete elucidation of the pathophysiological mechanisms of the PBE. 


\section{REFERENCES}

1. Antunes ACM, Torres, RV. Meningioma intracraniano: evolução histórica sobre seu conhecimento. In: Aguiar PHP, Ramina R, Veiga JCE, Tella O Jr (Eds). Meningiomas: diagnóstico e tratamento cirúrgico, aspectos atuais. Rio de Janeiro: Revinter, 2006:1-2.

2. Frosch MP, Anthony DC, Girolami UD. O sistema nervoso central. In: Kumar V, Abbas AK, Fausto N (Eds). Robbins e Cotran. Patologia: bases patológicas das doenças. $7^{\text {th }}$ Ed. Rio de Janeiro: Elsevier, 2005:1477-1478.

3. Al-Mefty O, Origitano TC. Meningiomas. In: Rengachary SS, Wilkins RH (Eds). Principles of neurosurgery. London: Wolfe, 1994:28,2-28,4.

4. Aguiar PHP. Edema peritumoral em meningiomas. In: Aguiar PHP, Ramina R, Veiga JCE, Tella O Jr (Eds). Meningiomas: diagnóstico e tratamento cirúrgico: aspectos atuais. Rio de Janeiro: Revinter, 2006:43-44.

5. Vignes JR, Sesay M, Rezajooi K, Gimbert E, Liguoro D. Peritumoral edema and prognosis in intracranial meningioma surgery. J Clin Neurosci 2008;15: 764-768.

6. Tamiya $T$, Ono $Y$, Matsumoto $K$, Ohmoto T. Peritumoral brain edema in in- tracranial meningiomas: effects of radiological and histological factors. Neurosurgery 2001;49:1046-1052

7. Souto AA, Chimelli L, Takya CM, Souza JM, Fonseca ALV, Silva LF. Edema cerebral em meningiomas: aspectos radiológicos e histopatológicos. Arq Neuropsiquiatr 2002;60:807-817.

8. Gurkanlar D, Er U, Sanli M, Özkan M, Sekerci Z. Peritumoral brain edema in intracranial meningiomas. J Cli Neurosci 2005;12:750-753.

9. Lee KJ, Joo WI, Rha HK, et al. Peritumoral brain edema in meningiomas: correlations between magnetic resonance imaging, angiography and pathology. Surg Neurol 2008;69:350-355.

10. Tatagiba M, Mirzai S, Samii M. Peritumoral blood flow in intracranial meningiomas. Neurosurgery 1991;28:400-404.

11. Nakano T, Asano K, Miura H, Itoh S, Suzuki S. Meningiomas with brain edema: radiological characteristics in MRI and review of literature. J Clin Imaging 2002;26:243-249.

12. Paek SH, Kim CY, Kim YY, Park IA, Kim MS. Correlation of clinical and biological parameters with peritumoral edema in meningiomas. J Neurooncol 2002; 60:235-245. 